\title{
SOIL ORGANIC MATTER DECOMPOSITION AND TURNOVER IN A TROPICAL ULTISOL: EVIDENCE FROM $\delta^{13} \mathrm{C}, \delta^{15} \mathrm{~N}$ AND GEOCHEMISTRY
}

\author{
Evelyn S Krull \\ CSIRO Land and Water, PMB 2, Glen Osmond SA 5064, Australia. Email: Evelyn.Krull@csiro.au. \\ Erick A Bestland \\ School of Chemistry, Physics and Earth Sciences, Flinders University, GPO Box 2100, Adelaide SA 5051, Australia \\ Will P Gates \\ CSIRO Land and Water, PMB 2, Glen Osmond SA 5064, Australia
}

\begin{abstract}
Soil organic matter (SOM), leaf litter, and root material of an Ultisol from the tropical rainforest of Kakamega, Kenya, were analyzed for stable carbon $\left(\delta^{13} \mathrm{C}\right)$ and nitrogen $\left(\delta^{15} \mathrm{~N}\right)$ isotopic values as well as total organic carbon (TOC) and total nitrogen $(\mathrm{TN})$ contents in order to determine trends in SOM decomposition within a very well-developed soil under tropical conditions. In addition, we quantified mineralogy and chemistry of the inorganic soil fraction. Clay mineralogical variation with depth was small and the abundance of kaolin indicates intense weathering and pedoturbation under humid tropical conditions. The soil chemistry was dominated by silica, aluminium, and iron with calcium, potassium, and magnesium as minor constituents. The relative depletion of base cations compared with silica and aluminium is an indicator for intense weathering and leaching conditions over long periods of time. Depth profiles of $\delta^{13} \mathrm{C}$ and $\delta^{15} \mathrm{~N}$ showed a distinct enrichment trend down profile with a large (average ${ }^{13} \Delta \mathrm{C}=5.0 \%$ and average ${ }^{15} \Delta \mathrm{N}=6.3 \%$ ) and abrupt offset within the uppermost 10 $20 \mathrm{~cm}$ of the soil. Isotopic enrichment with depth is commonly observed in soil profiles and has been attributed to fractionation during decomposition. However, isotopic offsets within soil profiles that exceed $3 \%$ are usually interpreted as a recent change from $\mathrm{C}_{4}$ to $\mathrm{C}_{3}$ dominated vegetation. We argue that the observed isotopic depth profiles along with data from mineralogy and chemistry of the inorganic fraction from the Kakamega Forest soil are a result of intense weathering and high organic matter turnover rates under humid tropical conditions.
\end{abstract}

\section{INTRODUCTION}

The transformation of soil organic matter (SOM) during decomposition and stabilization of organic carbon in the long-term soil carbon pool is of increasing interest with regard to issues of $\mathrm{CO}_{2}$ uptake and carbon storage capacities in soils. The depth distribution of stable isotopes of carbon $\left(\delta^{13} \mathrm{C}\right)$ and nitrogen $\left(\delta^{15} \mathrm{~N}\right)$ together with total organic carbon (TOC) and total nitrogen (TN) from SOM has been used to investigate decompositional processes within soils of different climates and ecosystems (Karamanos et al. 1981; Nadelhoffer and Fry 1988; Becker-Heidmann 1989; Becker-Heidmann and Scharpenseel 1986, 1992a,b). We use the term "decomposition" in a broad sense as defined by Baldock and Skjemstad (2000) as the "sum of alteration, mineralization, and assimilation" in contrast to the more narrowly defined term "mineralization", meaning the "conversion of organic carbon to carbon dioxide via respiration".

Isotopic depth profiles of $\delta^{13} \mathrm{C}$ and $\delta^{15} \mathrm{~N}$ have been proven particularly useful in 1) assessing the degree of decomposition and mineralization of organic matter within different soil profiles, 2) characterizing different soil types according to their isotopic depth trend, and 3) modeling changes in carbon storage or release after land use and vegetation changes (e.g. Stout and Rafter 1978; Stout et al. 1981; Balesdent et al. 1987; Nadelhoffer and Fry 1988; Becker-Heidmann and Scharpenseel 1986, 1992a,b; Balesdent and Mariotti 1996; Boutton et al. 1998).

Decomposition within soils is accompanied by increasing $\delta^{13} \mathrm{C}$ and $\delta^{15} \mathrm{~N}$ values with depth (e.g. Stout and Rafter 1978; Stout et al. 1981; Nadelhoffer and Fry 1988; Becker-Heidmann and Scharpenseel 1986, 1992a,b). The extent of this isotopic enrichment depends largely on the degree of decomposition, which is mostly controlled by climate (temperature and precipitation). An alternative interpretation for ${ }^{13} \mathrm{C}$-enriched isotopic values with soil depth is a change from $\mathrm{C}_{4}$-dominated 
(relatively ${ }^{13} \mathrm{C}$-enriched) vegetation to $\mathrm{C}_{3}$-dominated (relatively ${ }^{13} \mathrm{C}$-depleted) vegetation sometime during recent soil history. Studies investigating recent changes in land use accompanied by isotopically distinct vegetation changes have documented rapid overprinting of the present vegetation on the previous carbon pool within the uppermost 10-20 cm of soils (Balesdent and Mariotti 1996; Boutton et al 1998; Kendall 1998).

Problems arise in the interpretation of the signal when vegetation change resulted from (unknown) climate-related changes rather than human-related changes in land use. Under these circumstances it is difficult to evaluate whether the ${ }^{13} \mathrm{C}$ enrichment with depth is due to decomposition or a change in vegetation types $\left(\mathrm{C}_{3}\right.$ vs. $\left.\mathrm{C}_{4}\right)$. Most interpretations assume decomposition and carbon turnover as the responsible agents when enrichment is between 2 and $4 \%$. For enrichment greater than $4 \%$ o vegetation change from $\mathrm{C}_{3}$ to $\mathrm{C}_{4}$ is considered the dominant factor (e.g. Boutton et al. 1998). Such assumptions can become highly speculative, though, when either the SOM is particularly welldecomposed (i.e. greatly ${ }^{13} \mathrm{C}$-enriched) or the vegetation change occurred among mixed vegetations, i.e. mixture of $\mathrm{C}_{3}$ and $\mathrm{C}_{4}$ plants with varying degrees of abundance (i.e. less ${ }^{13} \mathrm{C}$-enriched). This difficulty in interpreting isotopic depth trends demonstrates the necessity to supplement data from the soil organic carbon pool with independent data that can provide information about the degree of soil development, climate, and weathering regime. Clay mineralogy and geochemical elemental abundances have been used to characterize soils in terms of their degree of weathering and climatic setting (Strakhov 1967). For example, well-developed tropical forest $\left(\mathrm{C}_{3}\right)$ soils are characterized by a high depletion in base cations $(\mathrm{Ca}, \mathrm{Mg}, \mathrm{K}, \mathrm{Na})$, a clayey and often oxide-enriched subsurface $\mathrm{B}$ horizon, and abundance of base-poor clays such as kaolinite. By comparison, soils supporting a $\mathrm{C}_{4}$ vegetation, such as tropical grasslands, are generally, but not always, characterized by greater amounts of calcium as well as other base cations (Buol et al. 1989). $\mathrm{C}_{4}$ grasslands are generally in drier regions where weathering is less intense and base cation retention in clays is more likely. Therefore, if a climate-related vegetation change from $\mathrm{C}_{4}$ to $\mathrm{C}_{3}$ type vegetation was responsible for ${ }^{13} \mathrm{C}$ enrichment within a soil profile, this considerable change should have left evidence in the soil mineralogical and elemental record. Here, we demonstrate the combined use of $\delta^{13} \mathrm{C}$ and $\delta^{15} \mathrm{~N}$ as well as clay mineralogy and XRF data to assess the soil organic carbon and nitrogen dynamics within a tropical forest soil from Kakamega Forest, Kenya.

\section{FIELD SITE}

Kakamega Forest Reserve in western equatorial Kenya is located about $400 \mathrm{~km}$ northwest of Nairobi and $150 \mathrm{~km}$ west of the great Rift Valley (Figures 1 and 2). The forest is one of the last virgin tropical rainforests in this intensely cultivated agricultural area. The forest is situated at an altitude of 1500$1700 \mathrm{~m}$ and covers an area of $240 \mathrm{~km}^{2}$. The natural vegetation is comprised of tropical rainforest of Guineo-Congolian species, including Aningeria altissima, Milicia excelsia, Antiaris toxicaria, and Chrysophyllum albidum. It also has elements of montane forest from the Kenya Rift escarpment, including Olea capensis and Croton megalocarpus (Round-Turner 1994). The understory is dominated by shrub species of Dracaena and epiphytic bryophytes are common in the branches of larger trees (Round-Turner 1994). The bedrock is predominantly composed of Precambrian gneisses that weather into moderately fertile clay-loam soils. Annual precipitation averages $2040 \mathrm{~mm} / \mathrm{yr}$ with most of the rains falling between April and November. Mean annual temperatures do not vary considerably and range from a mean maximum of $27^{\circ} \mathrm{C}$ to a mean minimum of $15^{\circ} \mathrm{C}$ (Round-Turner 1994).

Kakamega Forest is considered a "living remnant" of the Pleistocene period, prior to the last glaciation, when higher rainfall resulted in extensive rainforests from west and central Africa to large areas of what is now Kenya and Uganda. As the climate became drier, during the last glacial maxi- 
mum and then again during the Holocene, the area covered with rainforest declined, leaving only few refugia behind, such as the Budongo, Kibale, and Bugoma forests in Uganda and Kakamega Forest in Kenya (Hamilton 1967; COHMAP Members 1988). Threatened by increasing human population and demand for firewood, Kakamega Forest was closed to settlement in the mid-1920s to impede the rapid decline of rainforest area. Today, Kakamega Forest supports a rich flora and fauna with almost 150 species of woody trees, shrubs, and vines and about 330 species of birds, abundant primates, snakes, amphibians, and butterflies (Round-Turner 1994).

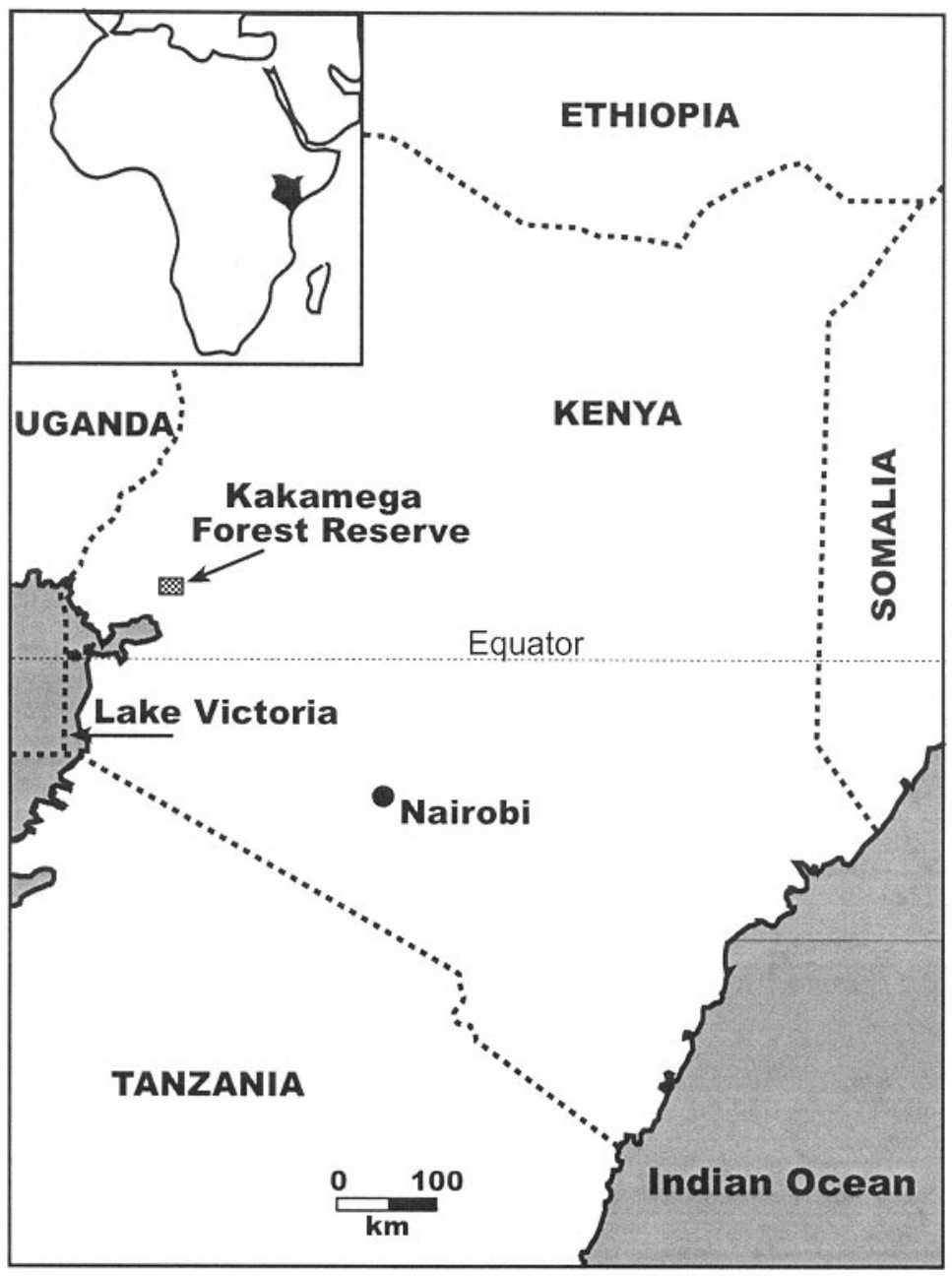

Figure 1 Location of Kakamega Forest in the western part of Kenya

\section{METHODS}

Samples were taken from an undisturbed soil profile on a gently sloping, well-drained site in the southeastern part of the forest (Figure 2). We sampled from the upper surface of the soil to a depth of $74 \mathrm{~cm}$ and included leaf litter as well as roots. The soil was characterized in the field, including estimates of grainsize and texture and determination of soil color (Figure 3). 
Figure 2 Location of sampling site within the Kakamega Forest Reserve

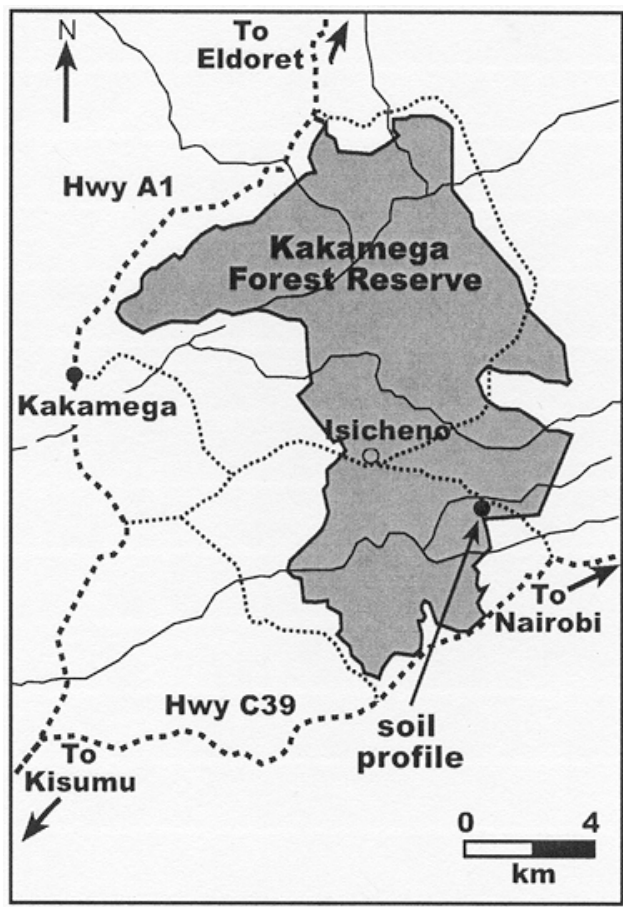

\section{Stable Isotopic Analyses}

In preparation for isotopic analysis, samples were finely ground and oven-dried at $60{ }^{\circ} \mathrm{C}$ for 12 hours. Roots and large organic debris were removed beforehand for individual isotopic analysis. Samples were divided into two sets. One set was treated for one hour at room temperature with $2 \mathrm{~N}$ $\mathrm{HCl}$ to remove carbonates and other acid-soluble minerals. Acid-insoluble residues were washed until neutral and oven-dried at $60{ }^{\circ} \mathrm{C}$ for 12 hours. The other set was left untreated. This approach was done to assess whether significant amounts of carbonate carbon and acid-soluble nitrogen species were present and how it would affect the $\delta^{13} \mathrm{C}$ and $\delta^{15} \mathrm{~N}$ values of treated versus untreated samples. Between 10-50 mg of sample mass was placed into ultra-clean tin capsules and sealed. Samples were combusted and analyzed on a 20-20 Europa Scientific Automated Nitrogen Carbon Analysis-Mass Specrometer (ANCA-MS). The reaction products from combustion were separated by gas chromatography to give pulses of pure $\mathrm{N}$ and $\mathrm{CO}_{2}$ for analysis of total carbon and nitrogen as well as $\delta^{13} \mathrm{C}$ and $\delta^{15} \mathrm{~N}$ values (Table 1).

The average error from replicates was $0.3 \%$ for $\delta^{13} \mathrm{C}$ and $0.5 \%$ for $\delta^{15} \mathrm{~N}$. Isotope results are reported in the conventional $\delta$ notation as per mil deviation from the PDB and $\mathrm{N}_{\text {air }}$ standards (Peterson and Fry 1987).

\section{X-ray Diffraction Analysis}

Each sample was mixed in an agate mortar and pestle before oven drying at $60^{\circ} \mathrm{C}$ overnight. The dried samples were then finely ground in an agate mortar and pestle prior to analysis. Samples were lightly pressed into aluminum sample holders for X-ray diffraction analysis. XRD patterns were recorded with a Philips PW1800 microprocessor-controlled diffractometer using Co K $\alpha$ radiation, variable divergence slit, and graphite monochromator. The diffraction patterns were recorded in 
steps of $0.05^{\circ} 2 \theta$ with a 3.0 second counting time per step, and logged to data files for analysis. Quantitative analysis was performed on the XRD data using the commercial package Siroquant from Sietronics Pty Ltd (Taylor 1991). The data was first background subtracted and calibrated for the automatic divergence slit. The average error was \pm 1.5 .

\section{Chemical Analysis by X-Ray Fluorescence}

Each sample was analyzed for total elemental composition by X-ray fluorescence spectroscopy using a Philips PW1480 on ignited $\left(1100{ }^{\circ} \mathrm{C}\right)$ samples fused with lithium borate glass (Norrish and Hutton 1969). Samples with a initially high organic matter content were reheated and fused two or three times to ensure complete dissolution of associated metals (e.g. Cr and Ni) into the flux.

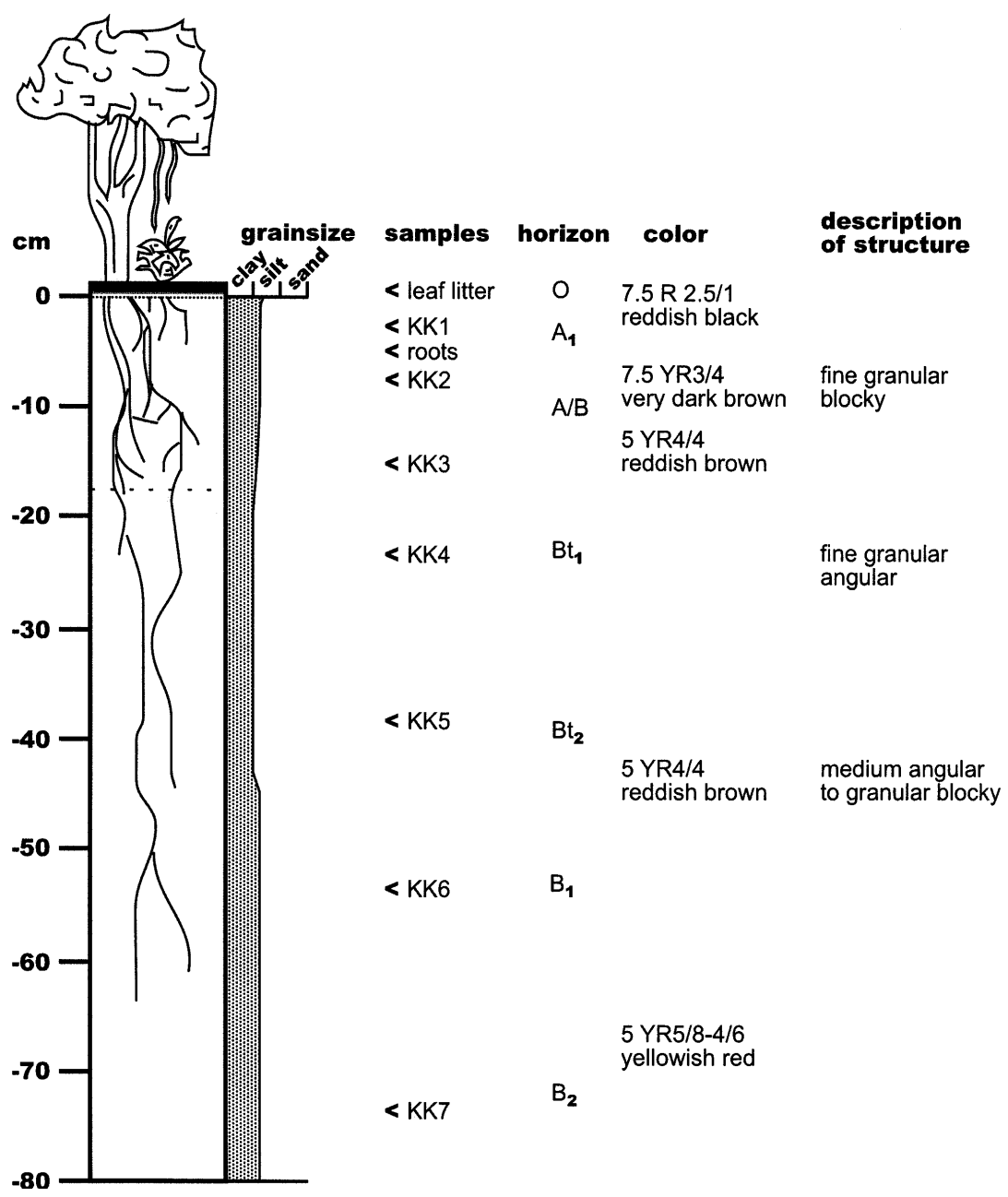

Figure 3 Kakamega Forest soil profile, showing sample numbers and depths, grainsize estimates, soil horizons, soil color, and description of soil textures 


\section{Cation Exchange Capacity Analysis}

The CEC of each sample was determined by depositing $80 \mathrm{mg}$ of sample, previously dispersed in $4 \mathrm{~mL}$ deionized water ( $\mathrm{pH} 6.8$ to 7.0), onto millipore filters. While vacuum was applied to the filterdeposit, a $2 \mathrm{~mL}$ aliquots of $1 \mathrm{M} \mathrm{BaCl}_{2}$ was added and allowed to pass through the sample. This step was repeated to ensure complete $\mathrm{Ba}^{2+}$ saturation. The samples were then washed ten times with $2 \mathrm{~mL}$ aliquots of deionized water and dried at $60{ }^{\circ} \mathrm{C}$. The $\mathrm{Ba}^{2+}$ concentrations were determined by $\mathrm{XRF}$ at the $\mathrm{Ba} \mathrm{L}_{\beta}$ fluorescence edge $(5.1565 \mathrm{eV})$ following matrix corrections. Cation exchange capacities were reported on an oven dried $\left(105^{\circ} \mathrm{C}\right)$ basis. The Mooring iolite reference material (Norrish and Pickering 1983) was used as a reference material to asses the accuracy of the values determined for the soils.

\section{RESULTS FROM XRD AND XRF ANALYSES}

Data from X-ray diffraction shows mineralogy dominated by quartz, kaolin, and mica, with minor components associated with feldspars and oxides (Table 2, Figure 4). Abundance with depth of quartz, kaolin, muscovite, and microcline remains very even, indicative of intense weathering over time. The slight increase in goethite with depth is most likely related to formation and accumulation of iron oxide, typical for tropical soils. The increase in kaolin and goethite is also indicative of a high degree of weathering of primary minerals in the profile.

X-ray fluorescence indicates soil chemistry dominated by silica, iron, and aluminum (Table 3, Figure 5). $\mathrm{SiO}_{2}$ constitutes the most abundant fraction (average $72.7 \mathrm{wt} . \%$ ), followed by $\mathrm{Al}_{2} \mathrm{O}_{3}$ (average 16.1 wt.\%) and $\mathrm{Fe}_{2} \mathrm{O}_{3}$ (average 7.7 wt.\%). The major oxide contents of $\mathrm{SiO}_{2}, \mathrm{Fe}_{2} \mathrm{O}_{3}$, and $\mathrm{Al}_{2} \mathrm{O}_{3}$ are consistent with the mineralogical data of the soil. In particular, the rather constant $\mathrm{K}_{2} \mathrm{O}$ contents are indicative of $8-10 \%$ micaceous mineralogy. The elevated $\mathrm{CaO}$ and $\mathrm{MgO}$ concentrations in the $\mathrm{A}_{1}$ horizon, followed by the drop to trace levels in the $\mathrm{B}_{\mathrm{t}}$, provide strong evidence of rapid nutrient turnover in the uppermost $10 \mathrm{~cm}$ of the soil.

Elevated concentrations of $\mathrm{Ni}$ and $\mathrm{Cr}$ were observed in the $\mathrm{A}_{1}$ and in the upper portion of the $\mathrm{Bt}_{2}$ horizon. High $\mathrm{Ni}$ and $\mathrm{Cr}$ concentrations in the $\mathrm{A}_{1}$ were associated with high organic carbon content $(17 \%)$ and with an increase in goethite in the upper $\mathrm{Bt}_{2}$, indicating probable mineralization of humic matter and eluviation of these metals. The CEC values for the Kakamega B horizons are low, ranging from 5 to $10 \mathrm{cmol} \mathrm{kg}^{-1}$ (Table 3). These values are within the range expected for soils whose mineralogy is dominated by quartz, kaolin and mica. Since the CEC was measured on samples bathed in near neutral $\mathrm{pH}$ solution, it is possible that the true CEC is underestimated with respect to the oxide fraction. Goethite commonly has a point of zero charge near $\mathrm{pH}$ 8.0-8.2. Significantly, the CEC values are highest in the $\mathrm{B}_{1}$ and the $\mathrm{B}_{\mathrm{t} 1}$ horizons, which contain about $1 \%$ total organic carbon. Thus, it is probable that up to half of the CEC in the upper B horizon of the Kakamega soil is associated with organic matter.

\section{Soil Classification}

The soil has been classified as an Ultisol as determined by the development of a definite argillic horizon and presence of primary minerals in excess of $10 \%$. Based on the enrichment in organic carbon of $>0.9 \%$ in the upper $15 \mathrm{~cm}$, probably less than $5^{\circ} \mathrm{C}$ annual temperature variation at $50 \mathrm{~cm}$ depth (i.e. isomesic soil temperature), no lithic contact within $50 \mathrm{~cm}$ of surface, and a CEC less than 24 meq/100 g, the soil can be classified as a Humoxic Tropohumult (Soil Survey Staff 1975). 

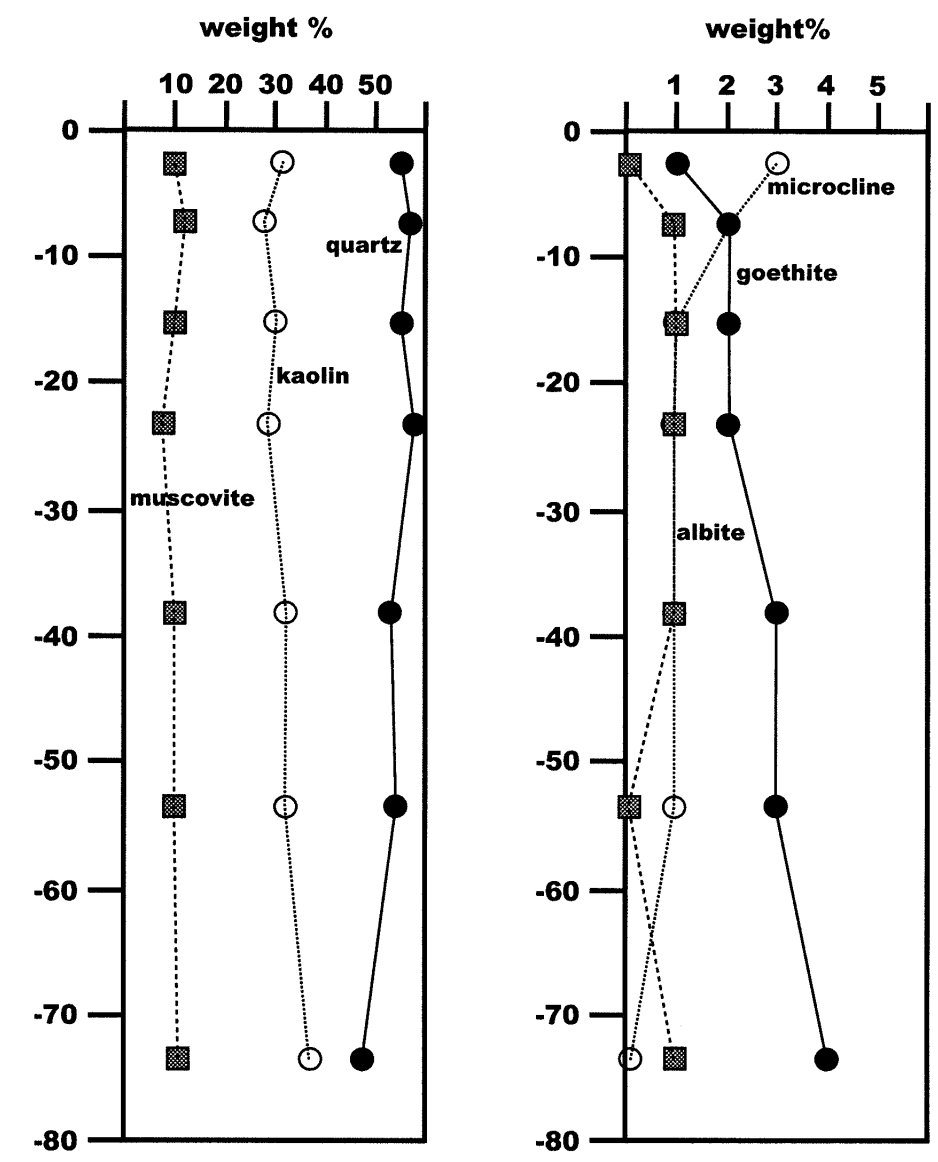

Figure 4 XRD depth profiles for quartz, kaolin, muscovite, microcline, goethite, and albite

\section{RESULTS OF $\delta^{13} \mathrm{C}$, TOC, $\delta^{15} \mathrm{~N}$, AND TN ANALYSES}

\section{Acid-Treated Samples}

$\delta^{13} \mathrm{C}$ and $\delta^{15} \mathrm{~N}$ values from plant material (leaf litter and roots) as well as the respective TN and TOC contents differed markedly from the average value of SOM. Carbon isotopic values from leaves and roots were $-27.3 \%$ and $-28.0 \%$, respectively, with TOC content for leaves averaging $40.3 \%$ and $29.2 \%$ for roots (Table 1A, Figure $6 \mathrm{~A}$ ). $\delta^{13} \mathrm{C}$ and $\delta^{15} \mathrm{~N}$ values of the soil profile showed a distinct depth trend towards more enriched values and decreased TOC and TN contents about $8 \mathrm{~cm}$ below the surface (Table 1A, Figures $6 \mathrm{~A}, \mathrm{~B})$. The $\delta^{13} \mathrm{C}$ value of the $\mathrm{O}$ horizon $(-27.7 \%$ ) was very similar to those of surface litter and roots, whereas TOC content was $60 \%$ less in the $\mathrm{O}$ horizon $(16.1 \%)$ compared with TOC content of leaf litter (40.3\%). Below the $\mathrm{O}$ horizon, $\delta^{13} \mathrm{C}$ values increased markedly by about $6.3 \%$ and reached the highest value of $-20.5 \%$ in the B horizon at $23 \mathrm{~cm}$ depth (Figure 6a). Lower in the profile, $\delta^{13} \mathrm{C}$ values decreased slightly by $0.8 \%$ and stabilized at $21.4 \%$. TOC values were considerably lower below the $\mathrm{O}$ horizon, decreasing continuously from $1.3 \%$ in the upper B to $0.5 \%$ in the lower B horizon (Table $1 \mathrm{~A}$ ).

$\delta^{15} \mathrm{~N}$ values in leaf litter (1.1\%o) were 3.3\%o depleted compared with the ones from the $\mathrm{O}$ horizon (4.4\%o) (Table 1B, Figure 6B). The most depleted $\delta^{15} \mathrm{~N}$ values occurred in the root tissue $(-3.6 \%$ ). By comparison, $\mathrm{TN}$ values in leaf litter and roots were similar (average $2.4 \%$ ) and decreased to $1.6 \%$ 
in the $\mathrm{O}$ horizon. Below the $\mathrm{O}$ horizon, $\delta^{15} \mathrm{~N}$ values increased rapidly by up to $3.2 \%$ and $\mathrm{TN}$ content decreased by an average of $1.5 \%$. The highest $\delta^{15} \mathrm{~N}$ values $(8.5 \%$ ) occurred in the deepest part of the soil at $74 \mathrm{~cm}$ depth. (Table 1B, Figure 6B).

$\mathrm{C} / \mathrm{N}$ ratios for the soil profile, including the leaf litter, averaged 11.1 and showed a pronounced decline from a high $\mathrm{C} / \mathrm{N}$ ratio in leaf litter of 18.6 to relatively homogenous values within the soil profile, where they averaged 10.0 (Table $1 \mathrm{C}$, Figure 7). $\mathrm{C} / \mathrm{N}$ ratios in roots were 11.2. A slight excursion to lower ratios (9.2) occurred in the B horizon at $23 \mathrm{~cm}$ (Figure 7).

Table $1 \mathrm{~A} \delta^{13} \mathrm{C}, \mathrm{TOC}, \delta^{15} \mathrm{~N}$, and TN for acidtreated samples

\begin{tabular}{l|llll}
\hline Samples & $\delta^{13} \mathrm{C}(\% \circ)$ & TOC $(\%)$ & $\delta^{15} \mathrm{~N}(\%)$ & $\mathrm{TN}(\%)$ \\
\hline Leaf litter & -27.3 & 40.3 & 1.1 & 2.16 \\
KK1 & -27.7 & 16.1 & 4.4 & 1.56 \\
KK2 & -22.4 & 1.3 & 6.5 & 0.13 \\
KK3 & -21.5 & 1.1 & 7.0 & 0.1 \\
KK4 & -20.5 & 0.6 & 6.9 & 0.06 \\
KK5 & -21.2 & 0.6 & 7.0 & 0.06 \\
KK6 & -21.3 & 0.6 & 7.6 & 0.06 \\
KK7 & -21.4 & 0.5 & 7.2 & 0.05 \\
Roots & -28.0 & 29.2 & -3.6 & 2.6 \\
\hline
\end{tabular}

Table $1 \mathrm{~B}{ }^{13} \mathrm{C}$, TOC, $\delta^{15} \mathrm{~N}$, and TN for untreated samples

\begin{tabular}{l|llll}
\hline Samples & $\delta^{13} \mathrm{C}(\%)$ & TOC $(\%)$ & $\delta^{15} \mathrm{~N}(\%)$ & $\mathrm{TN}(\%)$ \\
\hline Leaf litter & -27.3 & 40.3 & 1.1 & 2.16 \\
KK1 & -27.6 & 15.4 & 4.4 & 1.47 \\
KK2 & -23.0 & 1.3 & 6.8 & 0.13 \\
KK3 & -21.7 & 1.2 & 7.4 & 0.11 \\
KK4 & -20.6 & 0.7 & 8.2 & 0.07 \\
KK5 & -20.9 & 0.7 & 8.3 & 0.07 \\
KK6 & -21.2 & 0.6 & 8.2 & 0.06 \\
KK7 & -21.3 & 0.5 & 8.5 & 0.04 \\
Roots & -28.0 & 29.2 & -3.6 & 2.6 \\
\hline
\end{tabular}

Table $1 \mathrm{C} \mathrm{C} / \mathrm{N}$ ratio for acid-treated $\mathrm{C}$ and untreated $\mathrm{N}$ samples

\begin{tabular}{lr}
\hline Samples & C/N \\
\hline Leaf litter & 18.6 \\
KK1 & 10.3 \\
KK2 & 10.1 \\
KK3 & 9.7 \\
KK4 & 9.2 \\
KK5 & 9.7 \\
KK6 & 9.4 \\
KK7 & 11.6 \\
Roots & 11.2 \\
\hline
\end{tabular}

\begin{tabular}{lc} 
Table 1D Predicted $\delta^{13} \mathrm{C}$ depth distribution \\
\hline Samples & $\delta^{13} \mathrm{C}-\mathrm{p}$ \\
\hline Leaf litter & \\
KK1 & -25.9 \\
KK2 & -21.6 \\
KK3 & -21.3 \\
KK4 & -20.4 \\
KK5 & -20.4 \\
KK6 & -20.2 \\
KK7 & -19.9 \\
Roots & \\
\hline
\end{tabular}

\section{Non-Acid Treated Samples}

$\delta^{13} \mathrm{C}$ values and TOC content for non-acid treated samples did not show statistically different variation from the acid-treated samples (Tables $1 \mathrm{~A}, \mathrm{~B}$, Figure 6A). Average $\delta^{13} \mathrm{C}$ values for non-acid treated soil samples were $-22.4 \%$ compared with an average of $-22.3 \%$ o for acid-treated samples. Similarly, no significant loss of TOC was observed after acid treatment with both sample sets averaging 3.0\% (Tables 1A,B).

By comparison, $\delta^{15} \mathrm{~N}$ values showed significant differences upon treatment. Acid-treated samples were ${ }^{15} \mathrm{~N}$-depleted by an average of $0.8 \%$ with maximum depletion up to $1.4 \%$ (Tables $1 \mathrm{~A}, \mathrm{~B}$, Figure $6 \mathrm{~B})$. This resulted in average $\delta^{15} \mathrm{~N}$ values of $7.4 \%$ o for non-acid treated soil samples compared with $6.6 \%$ for acid-treated soil samples. Surprisingly, TN contents did not show significant losses after acid treatment, as average TN contents were only between $0.005 \%$ and $0.01 \%$ lower (Tables $1 \mathrm{~A}, \mathrm{~B}$ ). 
weight \%

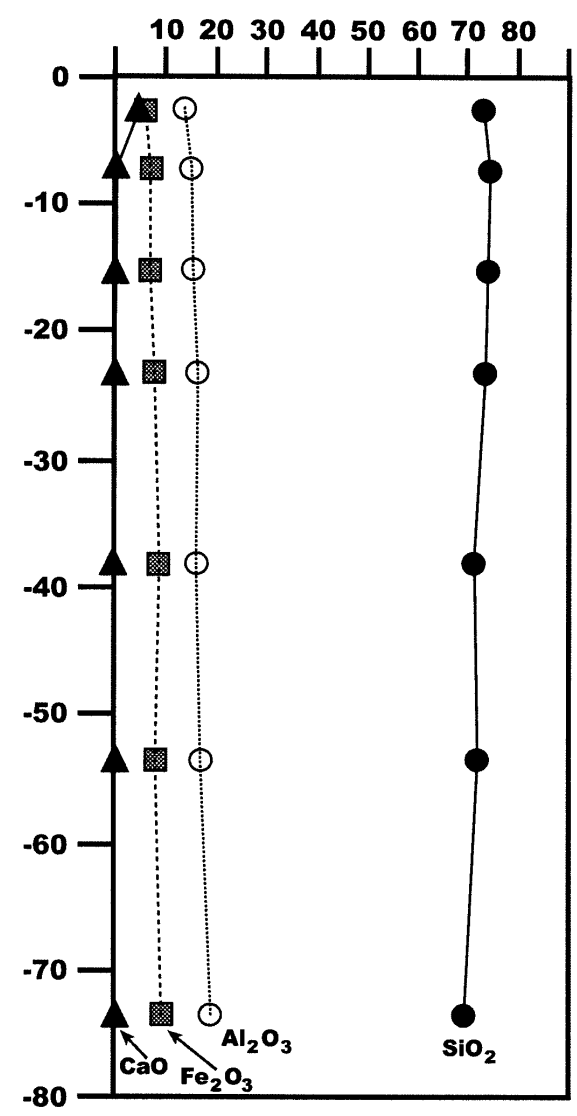

weight $\%$

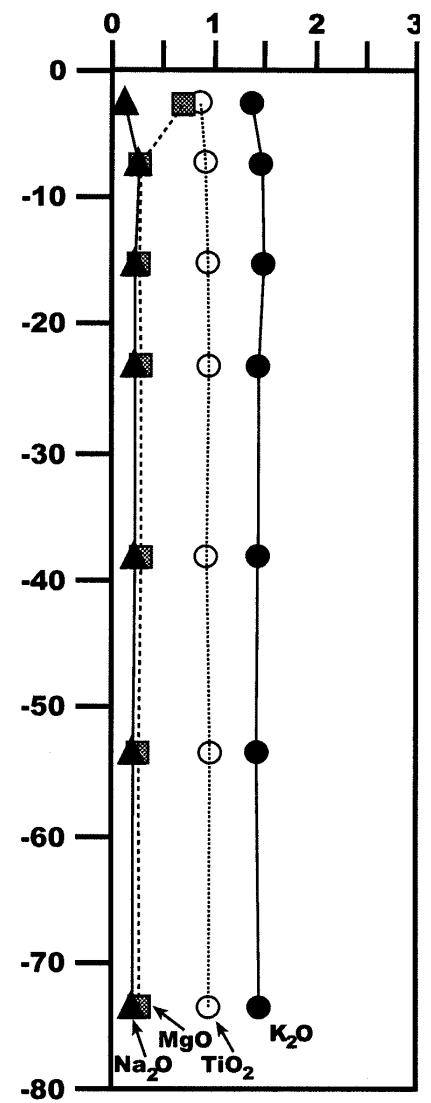

Figure 5 XRF depth profiles for $\mathrm{SiO}_{2}, \mathrm{Al}_{2} \mathrm{O}_{3}, \mathrm{Fe}_{2} \mathrm{O}_{3}, \mathrm{CaO}, \mathrm{K}_{2} \mathrm{O}, \mathrm{MgO}, \mathrm{TiO}_{2}$, and $\mathrm{Na}_{2} \mathrm{O}$

Nonetheless, the same degree of enrichment with depth as with acid-treated samples is observed. $\delta^{15} \mathrm{~N}$ values showed a rapid increase to $6.8 \%$ o below the $\mathrm{O}$ horizon with the enrichment trend continuing with depth to maximum values of $8.5 \%$ in the lowermost part of the soil (Table 1B, Figure 6B).

\section{DISCUSSION}

\section{Acid Versus Non-Acid Treated Samples}

From our comparison of acid and non-acid treated TOC and $\delta^{13} \mathrm{C}$ values we conclude that carbonate minerals were not present in any significant amounts in the soil because TOC did not show significant losses and $\delta^{13} \mathrm{C}$ did not show significant ${ }^{13} \mathrm{C}$-enrichment. Lack of calcite was also confirmed by $\mathrm{XRD}$ analysis. Absence of carbonate phases within the soils is to be expected under tropical conditions with annual rainfall in excess of $2000 \mathrm{~mm} / \mathrm{yr}$ (Birkeland 1999).

The significant ${ }^{15} \mathrm{~N}$-enrichment in the non-acid treated soil samples compared with the acid-treated samples indicates alteration upon acid treatment. Goering et al. (1990) noted variable changes in $\delta^{15} \mathrm{~N}$ in several natural samples upon acid treatment. These changes were attributed to different rates of leaching of organic $\mathrm{N}$ from compounds with different $\delta^{15} \mathrm{~N}$ values. Acid-hydrolysis studies by Stevenson (1956) and Senwo and Tabatabai (1998) show that acid-hydrolyzable amino-acids com- 
Figure 6 A: Depth profiles of acidtreated and non-acid treated $\delta^{13} \mathrm{C}$ values; B: Depth profiles of acid-treated and non-acid treated $\delta^{15} \mathrm{~N}$ values
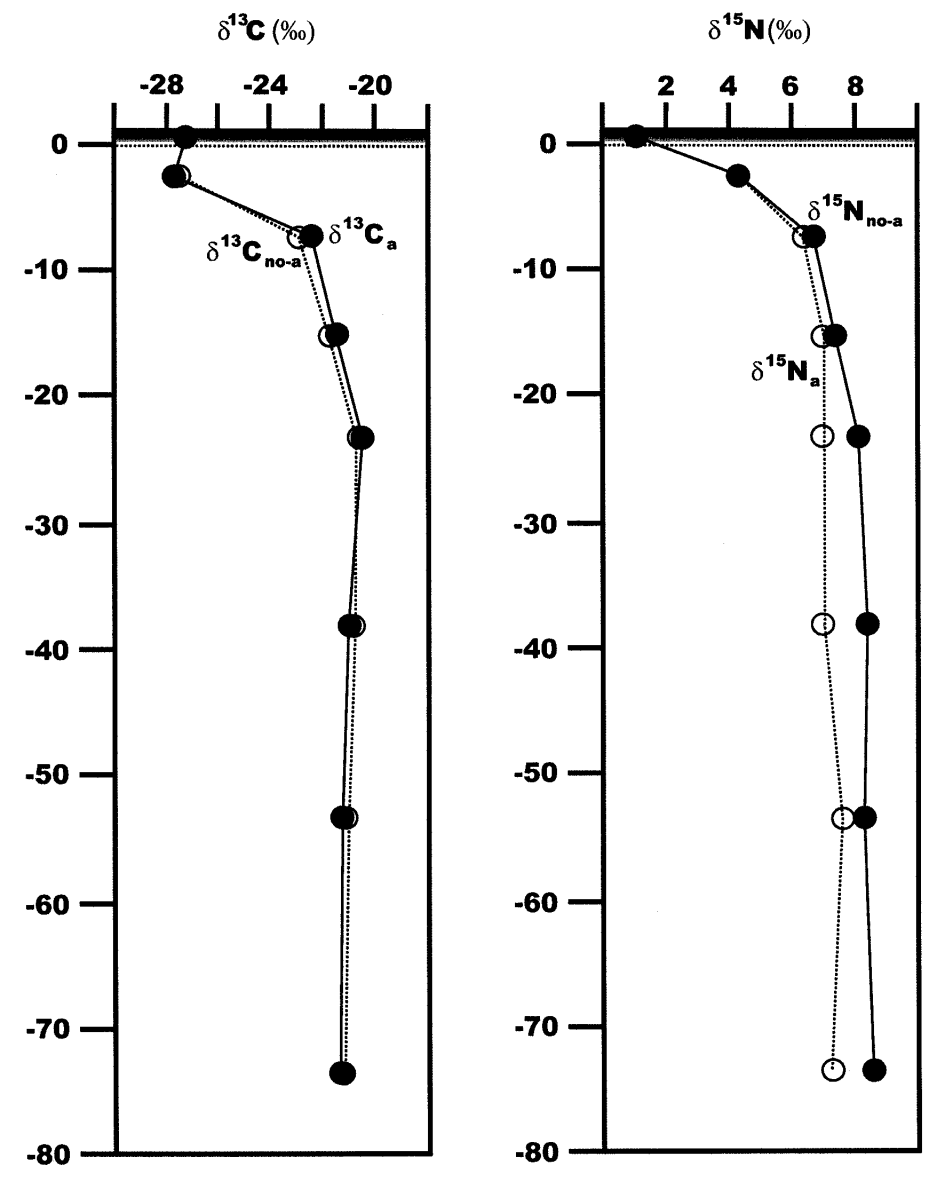

A

$\mathbf{B}$

prise $20-60 \%$ of the total soil $\mathrm{N}$ pool. In a study of compound specific $\delta^{15} \mathrm{~N}$ values from different soils, Ostle et al. (1999) demonstrated that acid-hydrolyzable amino-acids are by up to $2.5 \%{ }^{15} \mathrm{~N}$ enriched compared to bulk $\delta^{15} \mathrm{~N}$ values. Therefore, the significant depletion in $\delta^{15} \mathrm{~N}$ values in the acid-treated fraction of the Kakamega Forest soil by $1.4 \%$ is attributed to a loss of acid-hydrolyzable amino acids. Consequently, we used the strategy suggested by Bunn et al. (1995) to separately analyze non-acid treated samples for $\delta^{15} \mathrm{~N}$ and acid-treated samples for $\delta^{13} \mathrm{C}$ and focus our interpretation on these values (Figure 8).

\section{TN and $\delta^{15} \mathrm{~N}$}

The relatively high average $\delta^{15} \mathrm{~N}$ value (7.4\%o) in the SOM is typical for tropical ecosystems where $\mathrm{N}$ is not a limiting nutrient (Martinelli et al. 1999). Compared with soils from temperate forests with average $\delta^{15} \mathrm{~N}$ values of $2.5 \%$, soils from tropical forests show values of around $10.4 \%$ (Martinelli et al. 1999). Similarly, Martinelli et al. (1999) reported $\delta^{15} \mathrm{~N}$ values from foliage in tropical forests averaging $3.7 \pm 3.5 \%$, compared with depleted $\delta^{15} \mathrm{~N}$ values from temperate forests, averaging -2.8 $\pm 2.0 \%$. The large variation in these $\delta^{15} \mathrm{~N}$ values in foliage from tropical forests is due to much lower $\delta^{15} \mathrm{~N}$ values from forests developed on white-sand and from low-N montane forests (Martinelli et al. 
Table 2 XRD data for Kakamega Forest soil profile

\begin{tabular}{l|rrrrrrr}
\hline Samples & \multicolumn{1}{|c}{ KK1 } & KK2 & KK3 & KK4 & KK5 & KK6 & KK7 \\
\hline Quartz (\%) & 56 & 57 & 56 & 58 & 53 & 54 & 47 \\
Kaolin (\%) & 31 & 28 & 30 & 29 & 32 & 32 & 37 \\
Muscovite (\%) & 9 & 11 & 10 & 8 & 10 & 10 & 11 \\
Goethite (\%) & 1 & 2 & 2 & 2 & 3 & 3 & 4 \\
Microcline (\%) & 3 & 2 & 1 & 1 & 1 & 1 & $<1$ \\
Albite (\%) & $<1$ & 1 & 1 & 1 & 1 & $<1$ & 1 \\
Calcite (\%) & $<1$ & - & - & - & - & - & - \\
Anatase (\%) & - & - & - & $<1$ & - & - & - \\
\hline
\end{tabular}

Table $3 \mathrm{XRF}$ and CEC data for Kakamega Forest soil profile

\begin{tabular}{l|rrrrrrr}
\hline $\mathrm{Samples}$ & \multicolumn{1}{|c}{$\mathrm{KK} 1$} & \multicolumn{1}{c}{$\mathrm{KK} 2$} & \multicolumn{1}{c}{$\mathrm{KK} 3$} & \multicolumn{1}{c}{$\mathrm{KK} 4$} & \multicolumn{1}{c}{$\mathrm{KK} 5$} & \multicolumn{1}{c}{$\mathrm{KK} 6$} & $\mathrm{KK} 7$ \\
\hline $\mathrm{SiO}_{2}(\%)$ & 71.5 & 74.4 & 73.8 & 72.5 & 71.5 & 72.0 & 69.4 \\
$\mathrm{Al}_{2} \mathrm{O}_{3}(\%)$ & 13.4 & 14.9 & 15.3 & 16.3 & 16.4 & 16.9 & 18.6 \\
$\mathrm{Fe}_{2} \mathrm{O}_{3}(\%)$ & 6.4 & 7.0 & 7.3 & 7.6 & 8.8 & 7.9 & 8.8 \\
$\mathrm{CaO}(\%)$ & 4.4 & 0.2 & 0.2 & 0.2 & 0.1 & 0.1 & 0.1 \\
$\mathrm{~K}_{2} \mathrm{O}(\%)$ & 1.3 & 1.5 & 1.5 & 1.4 & 1.4 & 1.4 & 1.4 \\
$\mathrm{MgO}(\%)$ & 0.7 & 0.3 & 0.3 & 0.3 & 0.3 & 0.3 & 0.3 \\
$\mathrm{Na}_{2} \mathrm{O}(\%)$ & 0.7 & 0.3 & 0.3 & 0.3 & 0.3 & 0.3 & 0.3 \\
$\mathrm{TiO}_{2}(\%)$ & 0.8 & 0.9 & 0.9 & 1.0 & 0.9 & 1.0 & 1.0 \\
$\mathrm{P}_{2} \mathrm{O}_{5}(\%)$ & 0.3 & 0.1 & 0.1 & 0.1 & 0.1 & 0.1 & 0.1 \\
$\mathrm{MnO}(\%)$ & 0.2 & 0.2 & 0.2 & 0.2 & 0.1 & 0.1 & 0.1 \\
$\mathrm{SO}(\%)$ & 0.4 & $<0.1$ & $<0.1$ & $<0.1$ & 0.0 & 0.0 & $<0.1$ \\
$\mathrm{Cl}(\%)$ & 0.0 & $<0.1$ & $<0.1$ & $<0.1$ & $<0.1$ & $<0.1$ & $<0.1$ \\
$\mathrm{Zn}(\mathrm{ppm})$ & 120.4 & 117.7 & 94.1 & 85.6 & 81.8 & 99.3 & 69.4 \\
$\mathrm{Cu}(\mathrm{ppm})$ & 63.2 & 51.7 & 57.6 & 50.9 & 59.7 & 49.4 & 51.2 \\
$\mathrm{Sr}(\mathrm{ppm})$ & 262.7 & 47.0 & 43.7 & 35.9 & 36.8 & 35.8 & 36.2 \\
$\mathrm{Zr}(\mathrm{ppm})$ & 314.4 & 263.5 & 254.9 & 265.9 & 255.6 & 261.8 & 265.2 \\
$\mathrm{Ni}(\mathrm{ppm})$ & 1128.9 & 132.0 & 551.3 & 665.2 & 180.6 & 38.1 & 48.6 \\
$\mathrm{Rb}(\mathrm{ppm})$ & 73.6 & 69.4 & 69.6 & 65.9 & 67.1 & 66.5 & 62.9 \\
$\mathrm{Ba}(\mathrm{ppm})$ & 193.5 & 232.1 & 228.0 & 194.4 & 172.8 & 165.1 & 167.8 \\
$\mathrm{~V}(\mathrm{ppm})$ & 73.4 & 60.9 & 80.0 & 78.2 & 84.1 & 75.5 & 80.5 \\
$\mathrm{Cr}(\mathrm{ppm})$ & 1202.5 & 145.2 & 186.5 & 713.1 & 143.3 & 116.6 & 124.4 \\
$\mathrm{La}(\mathrm{ppm})$ & 85.0 & 75.9 & 55.1 & 121.2 & 63.2 & 44.0 & 45.2 \\
$\mathrm{Ce}(\mathrm{ppm})$ & 246.1 & 54.6 & 106.6 & 102.9 & 92.7 & 110.7 & 129.1 \\
$\mathrm{~Pb}(\mathrm{ppm})$ & 35.2 & 35.4 & 32.3 & 23.1 & 32.8 & 31.4 & 14.0 \\
$\mathrm{Y}(\mathrm{ppm})$ & 40.7 & 17.7 & 18.7 & 14.7 & 19.7 & 16.4 & 13.5 \\
$\mathrm{Co}(\mathrm{ppm})$ & 45.4 & 38.8 & 45.6 & 43.0 & 28.2 & 29.3 & 14.7 \\
$\mathrm{Ga}(\mathrm{ppm})$ & 22.0 & 7.2 & 9.4 & 9.4 & 8.7 & 10.9 & 11.6 \\
$\mathrm{U}(\mathrm{ppm})$ & 47.5 & 0 & 0 & 0 & 0 & 0 & 0 \\
$\mathrm{Th}(\mathrm{ppm})$ & 49.5 & 0 & 5.5 & 0 & 3.1 & 1.5 & 0 \\
$\mathrm{As}(\mathrm{ppm})$ & 0 & 26.3 & 23.3 & 24.6 & 23.3 & 23.9 & 29.3 \\
$\mathrm{CEC}(\mathrm{meq} / 100 \mathrm{~g})$ & - & 9 & 7 & 5 & 5 & 5 & 5 \\
\hline
\end{tabular}


1999). When excluding these sites, average $\delta^{15} \mathrm{~N}$ values for foliage from tropical forests are $4.7 \pm 2.1 \%$. The $\delta^{15} \mathrm{~N}$ values from leaf litter $(1.1 \%$ ) and SOM (7.4\%o) from the Kakamega Forest soil lie within the range reported for tropical environments by Martinelli et al. (1999) (Figure 8).

A significant negative correlation $\left(\mathrm{R}^{2}=0.9\right)$ existed between $\delta^{15} \mathrm{~N}$ values and $\mathrm{TN}$ content of soil, roots, and leaf litter (Figure 9A). Because TN contents for leaf litter, roots, and $\mathrm{O}$ horizon are an order of magnitude larger than for the remaining soil, we separately correlated $\delta^{15} \mathrm{~N}$ values and TN of the soil (excluding the TN-rich $\mathrm{O}$ horizon) and a negative correlation with $\mathrm{R}^{2}=0.9$ was observed (Figure 9B). Nadelhoffer and Fry (1988) reported an analogous correlation, where TN losses from the soil result in ${ }^{15} \mathrm{~N}$-enrichment of the residual $\mathrm{N}$ pool. This trend is interpreted to be an effect of bacterial fractionation during mineralization (nitrification) of organic nitrogen within the soil and is indicated by the increasing $\delta^{15} \mathrm{~N}$ values with soil depth (Figure 8 ).

If we assume that TN and $\delta^{15} \mathrm{~N}$ from leaf litter represent the initial TN SOM pool (Andreux et al. 1990), then $94 \%$ of the mineralizable TN was consumed in the uppermost $7 \mathrm{~cm}$ of the soil accompanied by ${ }^{15} \mathrm{~N}$-enrichment of $5.7 \%$ (Figure 8 ). With increasing depth the remaining $\mathrm{N}$-pool was further reduced by $4 \%$ and fractionated by $1.7 \%$, resulting in mineralization of $98 \%$ of the initial TN input.

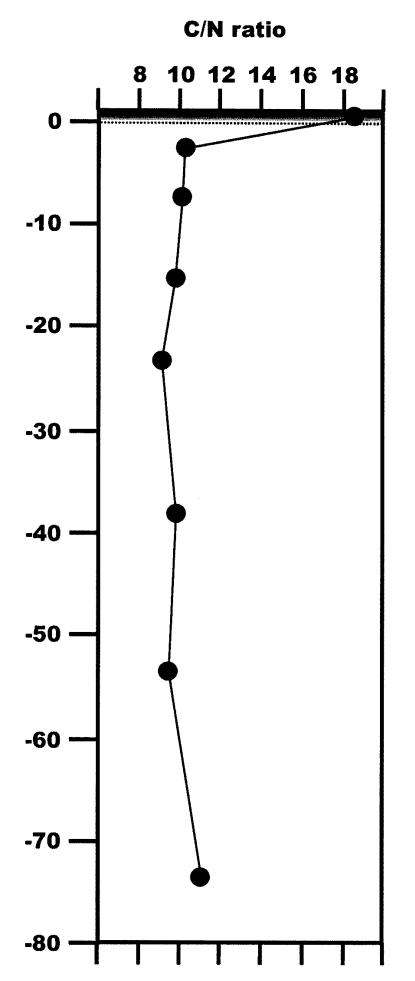

Figure $7 \mathrm{C} / \mathrm{N}$ ratio of acid-treated TOC samples and non-acid treated TN samples
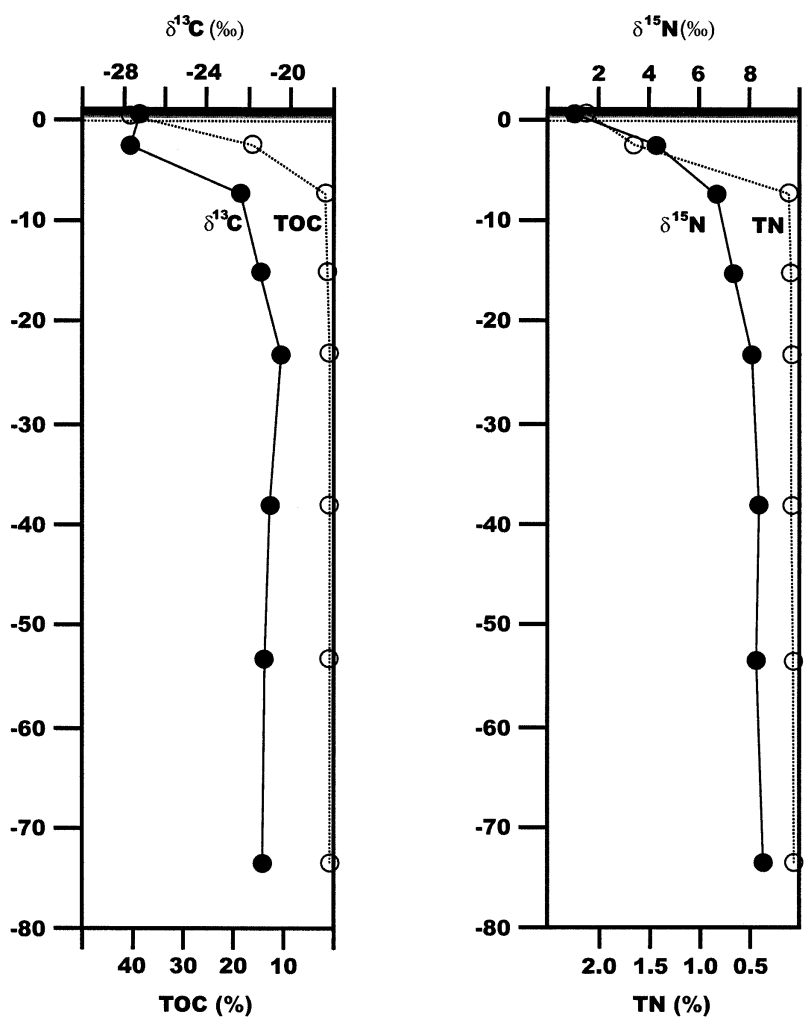

A

Figure 8 A: Depth profiles of acid treated $\delta^{13} \mathrm{C}$ and TOC values; B: Depth profiles of non-acid treated $\delta^{15} \mathrm{~N}$ and TN values 

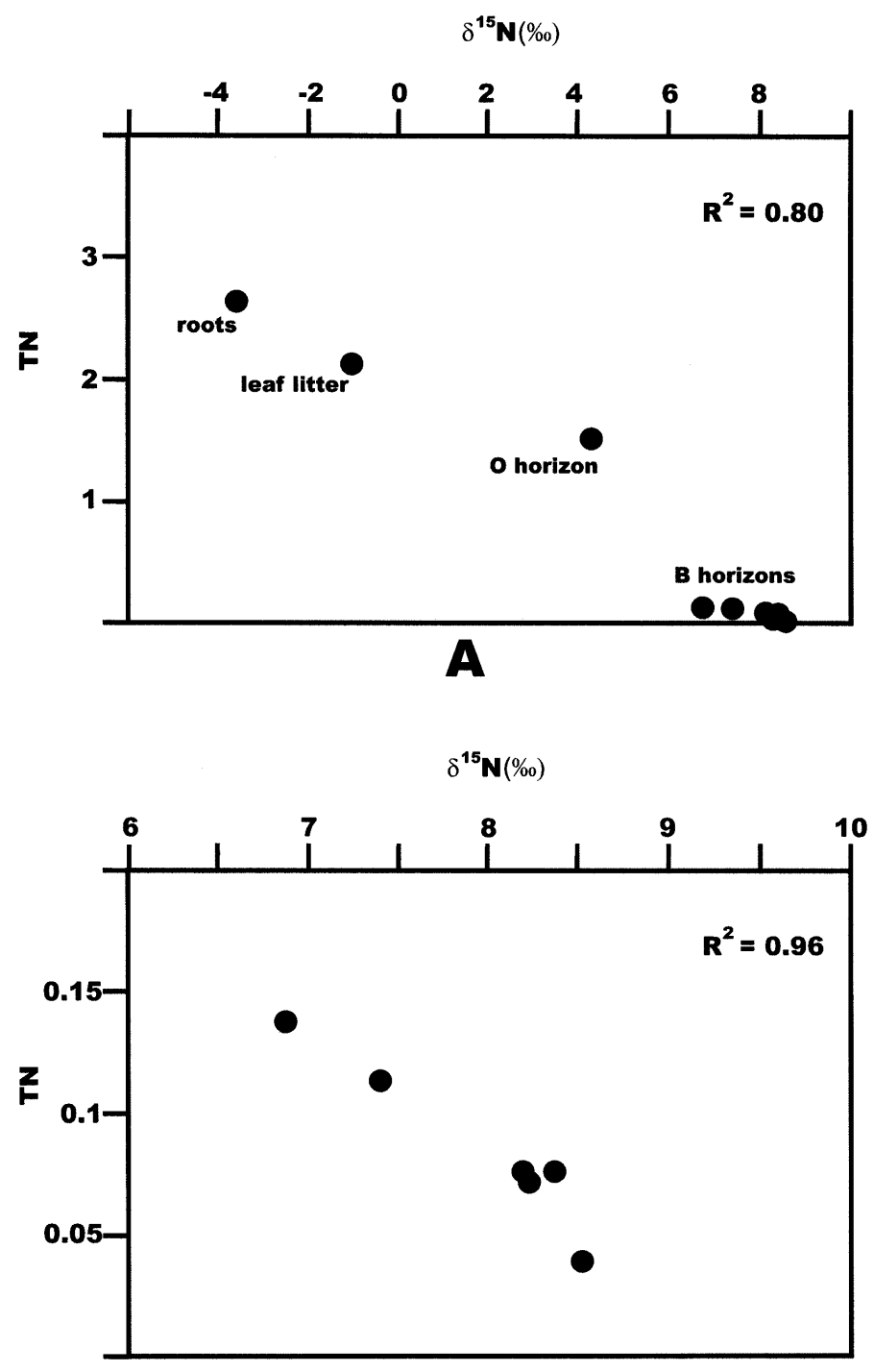

Figure 9 A: Scatter plot of $\delta^{15} \mathrm{~N}$ vs.\% $\mathrm{TN}$ values from all horizons, roots, and leaf litter; $\mathrm{R}^{2}=0.80$; B: Scatter plot of $\mathbf{B}$ $\delta^{15} \mathrm{~N}$ vs.\% TN values from $\mathrm{B}$ horizons only; $\mathrm{R}^{2}=0.96$

The $\delta^{15} \mathrm{~N}$ and TN depth trend illustrates the rapid mineralization and fractionation of nitrogenous organic matter (Figure 8). Prominent is the abrupt 3.5\% increase in $\delta^{15} \mathrm{~N}$ just $2.5 \mathrm{~cm}$ below surface and the continued increase until $\delta^{15} \mathrm{~N}$ values stabilize at around $8.2 \%$ at a depth of $23 \mathrm{~cm}$. Increases in $\delta^{15} \mathrm{~N}$ values in soils have been reported in other studies previously (Karamanos et al. 1981; Nadelhoffer and Fry 1988; Emmett et al. 1998; Martinelli et al. 1999) but with less detailed resolution than presented here.

An exception is the study by Mariotti et al. (1980) of temperate Inceptisols and one Spodosol where sample density was comparable to our study. However, mineralization (TN decline) and fractionation $\left(\delta^{15} \mathrm{~N}\right.$ increase) occurred at a slower rate than observed in the tropical Kakamega Forest soil. Thus, we interpret the relatively low values in the surface $\mathrm{O}$ horizon and the rapid enrichment with depth as a 
characteristic signature for tropical ecosystems where both organic matter decomposition and cycling of nutrients is rapid. In these soils the upper soil horizon becomes constantly replenished by fresh, ${ }^{15} \mathrm{~N}$-depleted leaf litter. The continuous ${ }^{15} \mathrm{~N}$-enrichment to a depth of about $23 \mathrm{~cm}$ indicates an intense rate of mineralization (nitrification) and fractionation, resulting in enrichment of the remaining $\mathrm{NH}^{4+}$ and soil organic-N pools (Vitousek 1984; Nadelhoffer and Fry 1988). Below $23 \mathrm{~cm} \delta^{15} \mathrm{~N}$ values stabilize which is probably the combined result of diminished bacterial activity and accumulation of refractory organic $\mathrm{N}$, as well as transport of ${ }^{15} \mathrm{~N}$-enriched soil humus particles downprofile and intense bioturbation by soil organisms (Steele et al. 1981; Nadelhoffer and Fry 1988). An interesting feature is the highly depleted $\delta^{15} \mathrm{~N}$ value in roots $(-3.6 \%$ ) (Table 1). Andreux et al. (1990) also observed that root tissue gave the lowest $\delta^{15} \mathrm{~N}$ values compared with leaves and SOM. We interpret this depletion as an effect of roots taking up the depleted fractionation products nitrite and nitrate from mineralization of labile organic $\mathrm{N}$ sources (Andreux et al. 1990). This is supported by the very similar isotopic offset between the $\delta^{15} \mathrm{~N}$ of leaf litter and the $\delta^{15} \mathrm{~N}$ of the $\mathrm{O}$ and A horizon $\left(\Delta^{15} \mathrm{~N}=4.5 \%\right.$, using a mean $\delta^{15} \mathrm{~N}$ value of 5.6\%o for the $\mathrm{O}$ and A horizon) compared with the offset between $\delta^{15} \mathrm{~N}$ of leaf litter with the $\delta^{15} \mathrm{~N}$ of roots $\left(\Delta^{15} \mathrm{~N}=4.7 \%\right.$ ) (Figure 10). We used the average $\delta^{15} \mathrm{~N}$ value of the $\mathrm{O}$ and A horizon because most mineralization and fractionation occurs in this interval and therefore most labile compounds taken up by plants are released here.

\section{$\delta{ }^{15} \mathbf{N}(\%)$}

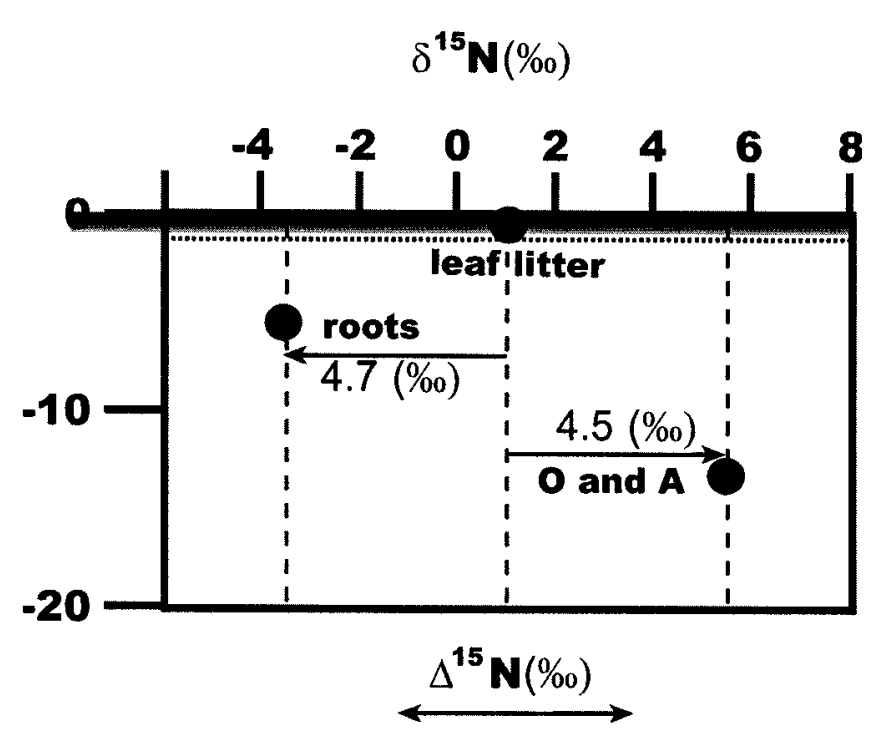

Figure $10 \Delta^{15} \mathrm{~N}$ differences between leaf lit-

ter, roots, and $\mathrm{O}$ and $\mathrm{A}$ horizons

TOC and $\delta^{13} \mathrm{C}$

$\delta^{13} \mathrm{C}$ values from leaf litter $(-27.3 \%$ ), roots $(-28.0 \%$ ), and O-horizon $(-27.7 \%$ ) fall clearly in the range of $\mathrm{C}_{3}$ plants (average $=-28 \%$, O'Leary 1988; average $=-26 \%$, Deines 1980). By comparison, average $\delta^{13} \mathrm{C}$ values from SOM $(-21.4 \%$ ) are enriched and could be interpreted as derived from intense fractionation during decomposition (Pessenda et al. 1996a) or from a mix of $\mathrm{C}_{3}$ and $\mathrm{C}_{4}$ vegetation (Pessenda et al. 1996b, 1998). This aspect will be discussed in detail in the following section.

The isotopic depth trend in the Kakamega Forest soil is unusual as the enrichment with depth is: 1) relatively large $\left(\Delta^{13} \mathrm{C}=7.2 \%\right.$ ), and 2$)$ occurs rapidly over an interval of $20 \mathrm{~cm}$ from the $\mathrm{O}$ horizon (Figure 8). Assuming that TOC and $\delta^{13} \mathrm{C}$ from leaf litter represent the original mineralizable organic carbon (Andreux et al. 1990), then $60 \%$ of mineralization occurred in the uppermost $2.5 \mathrm{~cm}$ and at $7 \mathrm{~cm}$ depth $97 \%$ of organic carbon was mineralized, accompanied by a ${ }^{13} \mathrm{C}$-enrichment of $5.3 \%$ o 
(Figure 8). This trend in TOC and $\delta^{13} \mathrm{C}$ is very similar to the trend in TN and $\delta^{15} \mathrm{~N}$. With further mineralization of almost $99 \%$ of the original TOC pool, fractionation increased $\delta^{13} \mathrm{C}$ values by $1.8 \%$ at $23 \mathrm{~cm}$ depth.

Correlation between $\delta^{13} \mathrm{C}$ and TOC was significant with $\mathrm{R}^{2}=0.8$ for all values (Figure 11a) and $\mathrm{R}^{2}=$ 0.7 for the soil profile except for the TOC-rich O-horizon (Figure 11b). This correlation confirms the relationship of increasing $\delta^{13} \mathrm{C}$ values with increasing age and decomposition of SOM as reported in previous studies (O'Brien and Stout 1978; Stout and Rafter 1978; Ladyman and Harkness 1980; Nadelhoffer and Fry 1988; Becker-Heidmann and Scharpenseel 1986, 1992a, 1992b; Balesdent et al. 1993; Balesdent and Mariotti 1996). Changes in TOC and $\delta^{13} \mathrm{C}$ of SOM in $\mathrm{C}_{3}$ soils during decomposition have been successfully described using an approximation of Raleigh's equation (Balesdent and Mariotti 1996): $\delta=\delta_{0}+\varepsilon \ln \left(C / C_{0}\right)$, where $\delta_{0}$ and $C_{0}$ are $\delta^{13} \mathrm{C}$ and TOC values in initial samples (i.e. the leaf litter horizon), and $\varepsilon$ is the Raleigh fractionation coefficient associated with carbon mineralization $(\varepsilon=-1.71 \%$ o). Using this equation the actual measured degree of fractionation is very closely predicted by the calculated slope (Figure 12). The only deviation occurred below $23 \mathrm{~cm}$, where there is a slight decrease by $0.8 \%$. This feature has been observed in several other soil studies and has been attributed to translocation of soluble, relatively young and undecomposed organic matter downprofile (Martin et al. 1990; Becker-Heidmann and Scharpenseel 1986, 1992; Feng et al. 1999).

However, this explanation is not supported by the continuously decreasing TOC contents at these depth levels in this study. Instead, we interpret this $\delta^{13} \mathrm{C}$ inflection at $23 \mathrm{~cm}$ as a change from an actively fractionating isotopic system, dominated by decomposition, to an isotopic system that reached a steady state, dominated by mixing of SOM from different horizons by soil organisms. Therefore, we interpret the overall isotopic trend of a rapid and large $\delta^{13} \mathrm{C}$ increase as a result of fractionation due to intense decomposition over time under tropical conditions. However, such decompositional changes are usually reported to be in the order of 2-4\%o (Becker-Heidmann and Scharpenseel 1986; Nadelhoffer and Fry 1988; Balesdent et al. 1993; Balesdent and Mariotti 1996) and larger isotopic offsets have been generally attributed to either methane dynamics in Riceland soils (Neue et al. 1990) or to $C_{3} / C_{4}$ vegetation changes (Boutton et al. 1998; Pessenda et al. 1996b, 1998). Furthermore, environmental factors such as water stress (Farquhar and Richards 1984; Stewart et al. 1995) and enriched pre-industrial $\delta^{13} \mathrm{C} \mathrm{CO}_{2}$ (Balesdent and Mariotti 1996) can cause isotopic enrichment in SOM. Such effects would be expected to be relatively small because pre-industrial $\delta^{13} \mathrm{C}^{\mathrm{CO}_{2}}$ decreased by only 1.5\% from 1750 to 2000 (Balesdent and Mariotti 1996) and only changes from tropical conditions to severe water-stress under arid conditions would produce $\delta^{13} \mathrm{C}$ differences larger than 5\%o (Ehleringer and Cooper 1988). This kind of radical environmental change is not likely to have occurred at this site during the last 10,000 years (Round-Turner 1994).

\section{Decomposition Versus Vegetation Change}

The $\delta^{13} \mathrm{C}$ depth profile from Kakamega Forest exhibits a large isotopic offset between surface and subsurface SOM and highly enriched isotopic values in the subsurface. We interpret this pronounced depth trend as characteristic for relatively old, highly weathered soils in a tropical environment with a homogenous temperature regime and year-round precipitation. In tropical environments, carbon cycling occurs in a tight cycle and affects predominantly the uppermost $5 \mathrm{~cm}$ of the soil. Here, decomposition releases and returns nutrients from and to plants. Only intensely decomposed and highly fractionated recalcitrant organic matter accumulates in the deeper parts of the soil. Since most studies of carbon fractionation in soils are from temperate regions with a seasonal climate, weathering and decomposition are not expected to be as pronounced and fractionation not as large as in tropical soils. However, various studies attribute such large isotopic offsets to climate change 

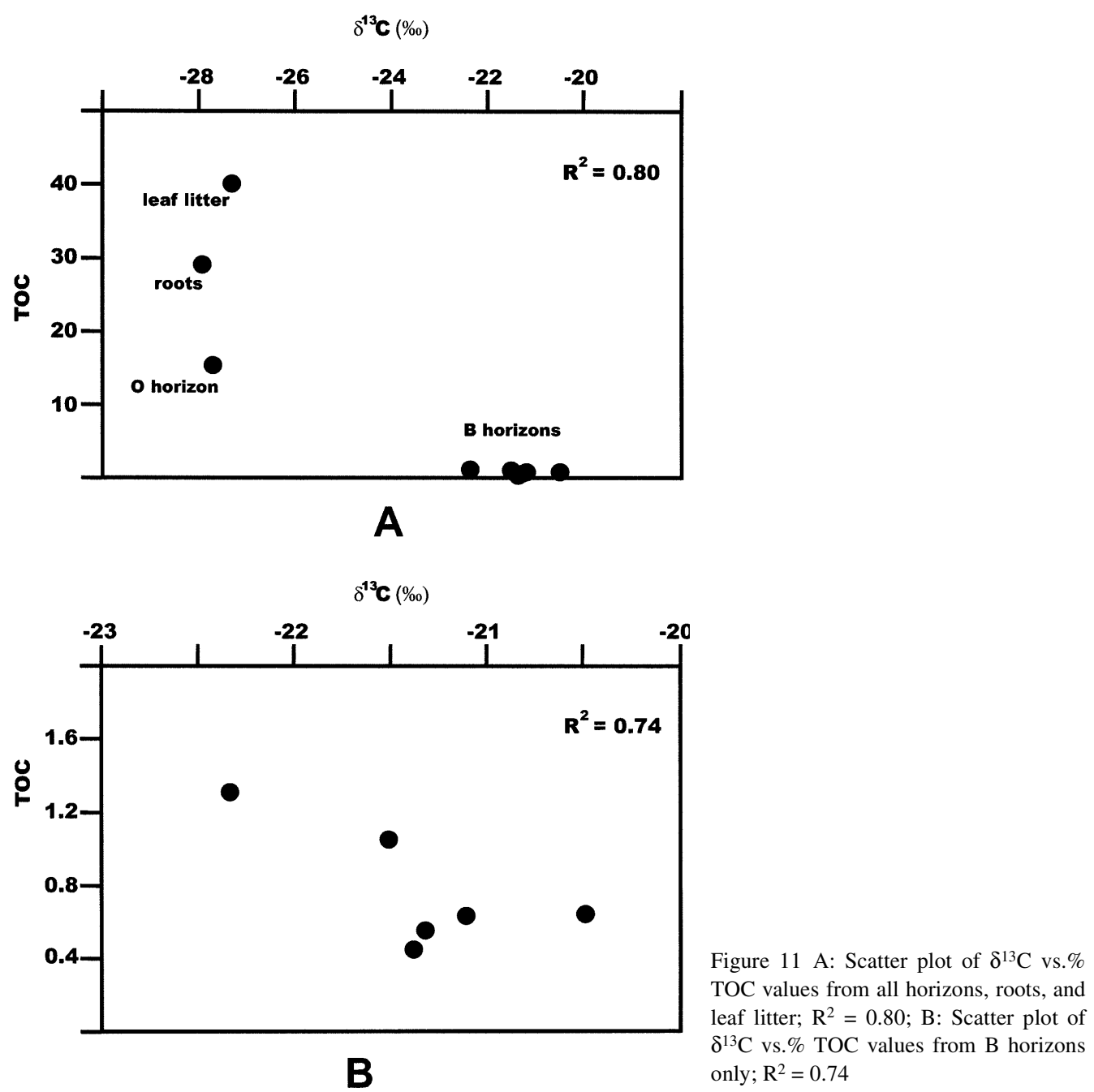

and a mix of $\mathrm{C}_{3}$ and $\mathrm{C}_{4}$ vegetation during the mid-Holocene (Boutton et al. 1998; Pessenda et al. $1996 \mathrm{~b}, 1998$ ). Average $\delta^{13} \mathrm{C}$ values for $\mathrm{C}_{4}$ vegetation are between $-14 \%$ (O'Leary 1988) and $-13 \%$ o (Deines 1980). Therefore, $\delta^{13} \mathrm{C}$ values of $-21 \%$, as seen in the Kakamega Forest soil, could indicate $37 \%$ contribution from $\mathrm{C}_{4}$ plants if increases due to decomposition are not taken into account (Boutton et al. 1998). Unfortunately, intense weathering and decomposition in tropical environments can completely destroy evidence such as phytoliths or pollen data, supportive of a climate-induced vegetation change. Therefore, other data is needed to confirm or oppose such a hypothesis. Several lines of evidence argue against vegetation change being responsible for the isotopic shift in the Kakamega Forest soil:

In the Kakamega Forest soil the $\delta^{13} \mathrm{C}$ shift towards enriched values occurs within the uppermost $10 \mathrm{~cm}$ of the soil. Several studies have investigated the isotopic dynamics of SOM after vegetation changes. Kendall (1998) reported that after about 100 years, following a $C_{3}$ to $C_{4}$ vegetation change, isotopic depth profiles of the studied soils showed an isotopic difference of $5.3 \%$ o between $\mathrm{C}_{4}$-dominated surface and $\mathrm{C}_{3}$-dominated subsurface soil $(0-20 \mathrm{~cm})$. A study by Boutton et al. (1998) 


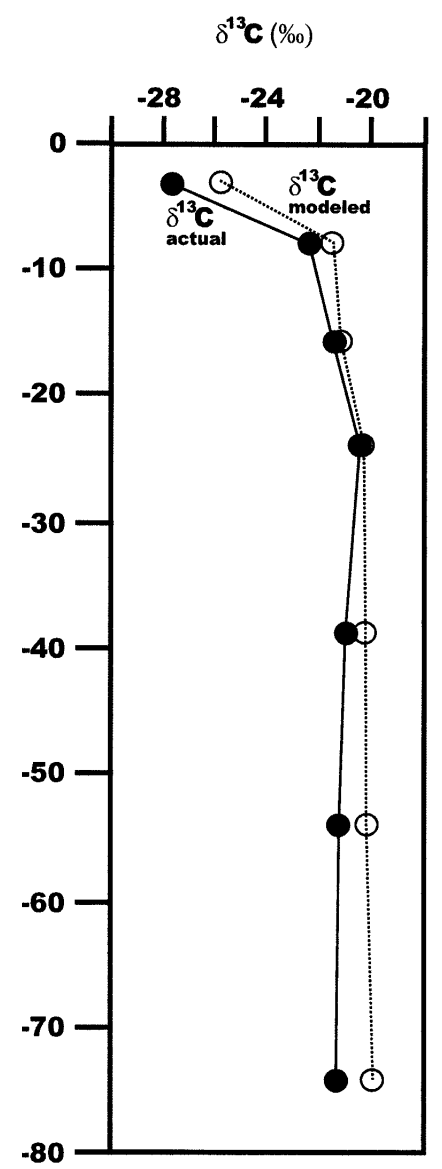

Figure 12 Depth profiles of predicted $\delta^{13} \mathrm{C}$ values and actual $\delta^{13} \mathrm{C}$ values; $\mathrm{R}^{2}=0.95$

reported an isotopic difference of $4 \%$ after 100 years following a change from $\mathrm{C}_{4}$ to $\mathrm{C}_{3}$ vegetation with the uppermost $0-15 \mathrm{~cm}$ averaging $-24 \%$ and $-20 \%$ o below this depth. Balesdent and Mariotti (1996) reported a $5.5 \%$ increase after only 23 years of $\mathrm{C}_{4}$ cultivation on previous $\mathrm{C}_{3}$-vegetated soils.

These studies show that the $\delta^{13} \mathrm{C}$ values of vegetation changes from $\mathrm{C}_{3}$ to $\mathrm{C}_{4}$ or vice versa become quickly incorporated into the $\delta^{13} \mathrm{C}$ of SOM and that they preserve a distinct depth trend in the uppermost 0-20 cm after only 100 years of change. Since the Kakamega Forest soil exhibits a similar trend one could argue that a change from $\mathrm{C}_{4} / \mathrm{C}_{3}$ mix to pure $\mathrm{C}_{3}$ vegetation could have occurred over the past 100 years. Given the record of Kakamega Forest as being a "living fossil" of the African Humid Period that started around 14.5 ka and peaked at around 9-6 ka ago (DeMenocal et al. 2000), it is unlikely that the large isotopic offset within the subsurface soil is due to a change of $\mathrm{C}_{3} / \mathrm{C}_{4}$ mixed vegetation to $\mathrm{C}_{3}$ tropical forest about 100 years ago. Old-growth trees present in the forest attest to the longevity of this forest ecosystem. Furthermore, the strong correlation of $\mathrm{R}^{2}=0.9$ between $\delta^{13} \mathrm{C}$ and $\delta^{15} \mathrm{~N}$ of SOM also suggests that decomposition was the main factor for the strong fractionation with depth because $\delta^{15} \mathrm{~N}$ in plants are not much affected by photosynthetic pathway and $\delta^{15} \mathrm{~N}$ in soils are controlled by decompositional processes (Mariotti et al. 1980; Nadelhoffer and Fry 1988; Kendall 1998; Turekian et al. 1998). 


\section{CONCLUSION}

Analyses of $\delta^{13} \mathrm{C}$ and $\delta^{15} \mathrm{~N}$ in conjunction with clay mineralogical and XRF data of an Ulitsol from Kakamega Forest indicate intense weathering and cycling of TOC and TN under tropical conditions. The large and abrupt increase of $\delta^{13} \mathrm{C}$ and $\delta^{15} \mathrm{~N}$ data by circa $7 \%$ within the uppermost $20 \mathrm{~cm}$ of the soil is interpreted to be a result of fractionation during decomposition under a tropical weathering regime. This is in contrast to other studies of similar isotopic depth trends which interpreted isotopic shifts larger than $4 \%$ o to changes between $\mathrm{C}_{3}$ and $\mathrm{C}_{4}$ vegetation types. Data from clay mineralogy and XRF also support large fractionation due to decomposition under intense tropical weathering rather than vegetation change. Clay mineralogical data as well as data from XRF analysis display very even depth trends, typical for an Ultisol that formed under a long period of weathering under tropical conditions.

\section{ACKNOWLEDGMENTS}

This work was supported by a grant from the National Geographic Society (grant number 6644-99). We thank E A Raven, G Riley, and M Amato of CSIRO Land \& Water for analytical support. The field research was done with the permission of the Government of Kenya, under the auspices of the Department of Palaeontology, National Museums of Kenya, and its head, M Leakey.

\section{REFERENCES}

Andreux F, Cerri C, Vose PB, Vitorello VA. 1990. Potential of stable isotopes ${ }^{15} \mathrm{~N}$ and ${ }^{13} \mathrm{C}$ : methods for determining input and turnover in soils. In: Harrison P, Ineson P, Heal OW, editors. Nutrient cycling in terrestrial ecosystems. Amsterdam: Elsevier Science Publishers Ltd. p 259-75.

Baldock JA, Skjemstad JO. 2000. Role of the soil matrix and minerals in protecting natural organic materials against biological attack. Organic Geochemistry 31: 697-710.

Balesdent J, Mariotti A. 1996 Measurement of soil organic matter turnover using ${ }^{13} \mathrm{C}$ natural abundance. In: Boutton TW, Yamasaki S, editors. Mass spectrometry of soils. New York: Marcel-Dekker, Inc. p 83-111.

Balesdent J, Girardin C, Mariotti A. 1993. Site-related $\delta^{13} \mathrm{C}$ of tree leaves and soil organic matter in a temperate forest. Ecology 74:1713-21.

Balesdent J, Mariotti A, Guillet B. 1987. Natural ${ }^{13} \mathrm{C}$ abundance as a tracer for studies of soil organic matter dynamics. Soil Biology and Biochemistry 19:25-30.

Becker-Heidmann P. 1989. Die Tiefenfunktionen der natürlichen Kohlenstoff-Isotopengehalte von vollständig dünnschichtweise beprobten Parabraunerden und ihre Relation zur Dynamik der organischen Substanz in diese Böden [PhD dissertation]: Hamburger Bodenkundliche Arbeiten 13: 1-228.

Becker-Heidmann P, Scharpenseel H-W. 1986. Thin layer $\delta^{13} \mathrm{C}$ and $\Delta^{14} \mathrm{C}$ monitoring of "lessive" soil profiles. Radiocarbon 28(2A ):383-90.

Becker-Heidmann P, Scharpenseel H-W. 1990. Carbon isotope dynamics in some tropical soils. Radiocarbon 31(3):672-9.

Becker-Heidmann P, Scharpenseel H-W. 1992a. The use of natural ${ }^{14} \mathrm{C}$ and ${ }^{13} \mathrm{C}$ in soils for studieson global climate change. Radiocarbon 34(3):535-40.

Becker-Heidmann P, Scharpenseel H-W. 1992b. Studies of soil organic matter dynamics using natural carbon isotopes. The Science of the Total Environment 117/ 118:305-12.

Birkeland PW. 1999. Soils and geomorphology. Third edition. New York: Oxford University Press.

Boutton TW, Archer SR, Midwood AJ, Zitzer SF, Bol R. 1998. $\delta^{13} \mathrm{C}$ values of soil organic carbon and their use in documenting vegetation change in a subtropical savanna ecosystem Geoderma 82:5-41.

Bunn SE, Loneragan NR, Kempster MA. 1995. Effects of acid washing on stable isotope ratios of $\mathrm{C}$ and $\mathrm{N}$ in penaeid shrimp and seagrass: Implications for food-web studies using multiple stable isotopes. Limnology and Oceanography 40:622-5.

Buol SW, Hole FD, McCracken RJ. 1989. Soil genesis and classification. Third edition. Ames: Iowa State University Press.

COHMAP Members. 1988. Climatic change of the last 18,000 years: observations and model simulations. Science 241:1043-52.

Deines P. 1980. The isotopic composition of reduced organic carbon. In: Fritz P, Fontes JC, editors. Handbook of environmental isotope geochemistry. Volume 1. The Terrestrial Environment, A. Amsterdam: Elsevier. p 329-406.

Ehleringer JR, Cooper TA. 1988. Correlations between carbon isotope ratio and microhabitat in desert plants. Oecologia 76:562-6.

Emmett BA, Kjønaas OJ, Gundersen P, Koopmans C, Tietema A, Sleep D. 1998. Natural abundance of ${ }^{15} \mathrm{~N}$ 
in forests across a nitrogen deposition gradient. Forest Ecology and Management 101:9-18.

Farquhar GD, Richards RA. 1984. Isotopic composition of plant correlates with water-use efficiency of wheat genotypes. Australian Journal of Plant Physiology 11: 539.

Feng X, Peterson JC, Quideau SA, Virginia RA, Graham RC, Sonder LJ, Chadwick OA. 1999. Distribution, accumulation, and fluxes of soil carbon in four monoculture lysimeters at San Dimas Experimental Forest, California, Geochimica et Cosmochimica Acta 63: 1319-33.

Goering J, Alexander V, Haubenstock N. 1990. Seasonal variability of stable carbon and nitrogen isotope ratios of organisms in a North Pacific bay, Estuarine Coastal Shelf. Science 30:239-60.

Hamilton A. 1967. The significance of patterns of distribution shown by forest plants and animals in tropical Africa for the reconstruction of Upper Pleistocene paleoenvironments: a review. In: van Zinderen Bakker EM, editor. Paleoecology of Africa. Volume 9. Cape Town: Balkema. p 63-97.

Karamanos RE, Voroney RP, Rennie DA. 1981. Variation in natural N-15 abundance of Central Saskatchewan soils. Soil Science Society of America Journal 45:8268.

Kendall C. 1998. Tracing nitrogen sources and cycling in catchments. In: Kendall C, McDonnell JJ, editors. Isotope tracers in catchment hydrology. Amsterdam: Elsevier Science. p 519-76.

Ladyman SJ, Harkness DD. 1980. Carbon isotope measurement as an index of soil development. Radiocarbon 22(3):885-91.

Mariotti A, Pierre D, Vedy JC, Bruckert S. 1980. The abundance of natural nitrogen-15 in the organic matter of soils along an altitudinal gradient. Catena 7:293300.

Martin A, Mariotti A, Balesdent J, Lavelle P, Vuattoux R. 1990. Estimate of organic matter turnover rate in a savanna soil by ${ }^{13} \mathrm{C}$ natural abundance measurements. Soil Biology and Biochemistry 22:517-23.

Martinelli LA, Pessenda LCR, Espinoza E, Camargo PB, Telles EC, Cerri CC, Victoria RL, Aravena R, Richey J, Trumbore S. 1996. Carbon-13 variation with depth in soils of Brazil and climate change during the Quaternary. Oecologia 106:376-81.

Martinelli LA, Piccolo MC, Townsend AR, Vitousek PM, Cuevas E, McDowell W, Robertson GP, Santos OC, Treseder K. 1999. Nitrogen stable isotopic composition of leaves and soil: tropical versus temperate forests. Biogeochemistry 46:45-65.

DeMenocal P, Ortiz J, Guilderson T, Adkins J, Sarntheim M, Baker L, Yarusinsky M. 2000. Abrupt onset and termination of the African Humid Period: rapid climate responses to gradual insolation forcing. Quaternary Science Reviews 19:347-61.

Nadelhoffer KJ, Fry B. 1988. Controls on natural nitro- gen-15 and carbon-13 abundances in forest soil organic matter. Soil Science Society of America Journal 52:1633-40.

Neue HU, Becker-Heidmann P, Scharpenseel, H-W. 1990. Organic matter dynamics, soil properties, and cultural practices in rice lands and their relationship to methane production. In: Bouwman AF, editor. Soils and the greenhouse effect. New York: John Wiley and Sons. p 457-66.

Norrish K, Hutton JT. 1969. An accurate X-ray spectroscopic method for the analysis of a wide range of geologic samples. Geochimica et Cosmochimica Acta 33: 431-53.

Norrish K, Pickering JG. 1983. Clay minerals. In: CSIRO Division of Soils, editor. Soils, an Australian viewpoint. Melbourne: Academic Press. p 281-308.

O'Brien BJ, Stout JD. 1978. Movement and turnover of soil organic matter as indicated by carbon isotope measurements. Soil Biology and Biochemistry 10: 309-17.

O'Leary MH. 1988. Carbon isotopes in photosynthesis. BioScience 38:328-36.

Osle NJ, Bol R, Petzke KJ, Jarvis SC. 1999. Compound specific $\delta^{15} \mathrm{~N} \%$ values: amino acids in grassland and arable soils. Soil Biology and Biochemistry 31:17515.

Pessenda LCR, Aravena R, Melfi AJ, Telles EC, Boulet R, Valencia EPE, Tomazello M. 1996a. The use of carbon isotopes $\left({ }^{13} \mathrm{C},{ }^{14} \mathrm{C}\right)$ in soil to evaluate vegetation changes during the Holocene in central Brazil. Radiocarbon 38(2):191-201.

Pessenda LCR, Valencia EPE, Camargo PB, Tzelles EC, Martinelli LA, Cerri CC, Aravena R, Rozanski K. 1996b. Natural radiocarbon measurements in Brazilian soils developed on basic rocks. Radiocarbon 38(2):203-8.

Pessenda LCR, Gouveia SEM, Aravena R, Gomes BM, Boulet R, Ribeiro AS. $1998 .{ }^{14} \mathrm{C}$-dating and stable carbon isotopes of soil organic matter in forest-savanna boundary areas in the southern Brazilian Amazon region. Radiocarbon 40(2):1013-22.

Peterson BJ, Fry B. 1987. Stable isotopes in ecosystem studies. Annual Review of Ecological Systems 18:293320.

Round-Turner D, editor. 1994. Kakamega Forest, the official guide. Nariobi: Indigenous Forest Conservation Programme. $67 \mathrm{p}$.

Senwo ZN, Tabatabai MA. 1998. Amino Acid composition of soil organic matter. Biology and Fertility of Soils 26:235-42.

Soil Survey Staff. 1975. Soil taxonomy, handbook. U.S. Department of Agriculture No. 436.

Steele KW, Wilson AT, Saunders WMH. 1981. Nitrogen isotope ratios in surface and sub-surface horizons of New Zealand improved grassland soils. New Zealand Journal of Agricultural Research 24:167-70.

Stevenson FJ. 1956. Effect of some long-term rotations 
on the amino acid composition of the soil. Journal of the American Soil Science Society 20:204-8.

Stewart GR, Turnbull MH, Schmidt S, Erskine PD. 1995.

${ }^{13} \mathrm{C}$ abundance in plant communities along a rainfall gradient: a biological integrator of plant availability. Australian Journal of Plant Physiology 22:51-5.

Stout JD, Rafter TA. 1978. The ${ }^{13} \mathrm{C} /{ }^{12} \mathrm{C}$ isotopic ratios of some New Zealand tussock grassland soils. In: Stable isotopes in the earth sciences. New Zealand Department of Scientific and Industrial Research, DSIR Bulletin 220, INS Contribution no. 806. p 75-83.

Stout JD, Goh KM, Rafter TA. 1981. Chemistry and turnover of naturally occurring resistant organic compounds in soil. In: Paul EA, Ladd JN, editors. Soil biochemistry. New York: Marcel Dekker. p 19-24.

Strakhov NM. 1967. Principles of lithogenesis. Edinburgh: Oliver and Boyd Ltd.
Taylor JC. 1991. Computer programs for standardless quantitative analysis of minerals using the full powder diffraction profile. Powder Diffraction 6:2-9.

Turekian VC, Macko S, Ballentine D, Swap RJ, Garstang M. 1998. Causes of bulk carbon and nitrogen isotopic fractionations in the products of vegetation burns: laboratory studies. Chemical Geology 152:181-92.

Veldkamp E. 1994. Organic carbon turnover in three tropical soils under pasture after deforestation. Soil Science Society of America Journal 58:175-80.

Vitousek PM. 1984. Litterfall, nutrient cycling, and nutrient limitation in tropical forests. Ecology 65:28598.

Volkoff B, Cerri CC. 1987. Carbon isotopic fractionation in subtropical Brazilian grassland soils. Comparison with tropical forest soils. Plant and Soil 102:27-31 